\title{
Reaction Products of 4-Aza- and 4-Methyl-4-azacholest-5-en-3-one with Nitrous Acid
}

\author{
Masaru Kobayashi, Hideo Furuse and Hiroshi Mitsuhashi \\ Faculty of Pharmaceutical Sciences, Hokkaido University ${ }^{1}$
}

(Received October 5, 1971)

\begin{abstract}
Reaction of sodium nitrite with enamine-type lactams (II and IX) was studied. The products were identified as oxime (III), ketone (IV and V), and nitrile (VI) from II and oxime (X), nitrimine (XI), and nitrile (XII) from IX. These were formed by initial attack of the nitroso ion on $\mathrm{C}-6$ followed by concurrent fragmentation or hydrolysis. Formation of $\mathrm{N}$-nitroso derivatives or deaza compounds was not observed.
\end{abstract}

Nitrosation of saturated lactams gives N-nitroso derivatives which changes into corresponding lactones or unsaturated acids on thermal elimination of nitrogen. ${ }^{2}$ ) On the other hand, there has not been recorded the reaction of enamine lactams which have reactive $\alpha$-carbon toward electrophiles. In the case of the nitrosation of uracil derivatives, the reaction leads predominantly to the $\mathrm{C}$-nitroso derivatives, ${ }^{3)}$ while the nitrosation of a certain steroidal enamine results in the addition of nucleophile to $\alpha$-carbon by the influence of the intermediate diazonium group. ${ }^{4}$ From these examples, we became interested in the behavior and the products of the reaction of enamine lactams with nitrous acid. 4-Azacholest-5-en-3-one (II) is a readily available enamine lactam obtained by the reaction of ammonia and seco-acid ${ }^{5}$. (I). We have found that a simple heating of I in formamide affords II in quantitative yield and, in an analogous manner, $\mathrm{N}$-methyl derivative (IX) in a high yield when heated in methyl formamide. The lactam (II) was then allowed to react with sodium nitrite, varying the reaction temperature, time, and amount of reagents, and the products were separated mainly by chromatography. No trace of deaza products or stable $\mathrm{N}$-nitroso derivatives was found, and the reproducibility and yields of the products were rather low. Thus, the lactam (II), when reacted with 17.5 molar equivalents of sodium nitrite in acetic acid and acetic anhydride mixture at 0 to $-5^{\circ}$ for $3 \mathrm{hr}$ and the product crystallized from methanol, gave III, $\mathrm{mp}$ 172$173^{\circ}, \mathrm{C}_{27} \mathrm{H}_{46} \mathrm{O}_{3} \mathrm{~N}_{2}$, in $20 \%$ yield. Chromatography of the mother liquor gave IV, mp 194$195^{\circ}, \mathrm{C}_{27} \mathrm{H}_{45} \mathrm{O}_{3} \mathrm{~N}(2.6 \%)$, and $\mathrm{V}, \mathrm{mp} 211^{\circ}, \mathrm{C}_{26} \mathrm{H}_{43} \mathrm{O}_{3} \mathrm{~N}(3.4 \%)$, after crystallization from methanol. When II was treated with 5.6 equivalent moles of sodium nitrite at $0^{\circ}$ for $9 \mathrm{hr}, \mathrm{V}$ $(10 \%)$, VI, mp $154-155^{\circ}, \mathrm{C}_{26} \mathrm{H}_{42} \mathrm{O}_{2} \mathrm{~N}_{2}(4.2 \%)$, and a trace of VII, mp 224-225.5 obtained after chromatography and crystallization from methanol. In another run, when the lactam (II) was treated with 4.5 molar equivalents of sodium nitrite at $-5^{\circ}$ for $2 \mathrm{hr}, \mathrm{V}$ was isolated in $18 \%$ yield.

The structures of these products were deduced from their physical constants and elemental analyses as follows. Compound III was formulated as in Chart I since the infrared (IR) spectrum showed absorptions of lactam grouping at 3200, 3100, 1675, and 1660, and a hydroxyl at $3380 \mathrm{~cm}^{-1}$, while its nuclear magnetic resonance (NMR) spectrum showed a shielded OMe group at $\delta 2.94$ suggesting the presence of 6 -oximino-5-methoxy moiety which was

1) Location: Kita-12-jo, Nishi-5-chome, Sapporo, 060, Japan.

2) P. Bladon and W. McMeekin, J. Chem. Soc., 3504 (1961); G. Nischk and E. Müller, Ann., 576, 232 (1952).

3) H. Goldner, G. Dietz, and E. Carstens, Ann., 691, 142; W. Pfleiderer and G. Blankenhorn, Tetrahedron Letters, 1969, 4699.

4) L. Rodrigues-Hahn and J. Romo, Can. J. Chem., 46, 1529 (1968).

5) M. Uskokovic and M. Gut, Helv. Chim. Acta, 42, 2258 (1959). 
also supported by another characteristic signal of $7 \beta$-equatorial hydrogen syn to hydroxyl group at $\delta 3.35(\mathrm{~d}, J=12 \mathrm{~Hz})$ as reported for $5 \alpha$-substituted 6 -keto-steroid oximes. ${ }^{6}$ ) The structure of IV was assumed to be a 6-oxo derivative of III which was supported by the IR spectrum showing absorptions at $3220,3110,1685 \mathrm{~cm}^{-1}$ (lactam), and $1739 \mathrm{~cm}^{-1}$ (CO), and by the NMR absorption at $\delta 3.00$.

The structure of $\mathrm{V}$ was also assumed to be a 5-hydroxy derivative of IV since its IR spectrum showed absorptions at 3300, 1670, 1620 (lactam), and $1735 \mathrm{~cm}^{-1}$ (CO). The IR spectrum of VI showed absorptions at $3200,3100(\mathrm{NH}), 2250(\mathrm{CN}), 1720$, and $1700 \mathrm{~cm}^{-1}$ (CO), and these two carbonyl bands the lower frequency of which had stronger intensity exhibit the presence of a cyclic imide grouping in the molecule so that VI was considered to be 5,6-seco-imide nitrile. The IR spectrum of VII showed absorptions at 3180,3100, and $1680 \mathrm{~cm}^{-1}$ but its structure is not clear. The structures assumed as above were confirmed by direct correlations as follows. Since the reaction in acetic acid-acetic anhydride medium afforded variable products in low yields, we employed polyphosphoric acid because it serves as both strong acid and solvent. The lactam (II) when treated in polyphosphoric acid with 2.0 molar equivalents of sodium nitrite at room temperature for 10 min showed four spots, assumed to be a mixture of $5 \alpha$-phosphate esters, on thin-layer chromatography (TLC). The mixture was refluxed in methanol for a while and its TLC showed a single spot and, after crystallization, III was obtained almost quantitatively. From these evidences it became obvious that substitution at C-5 occurred readily in the reaction sequence and angular methoxyl groups in III and IV were derived from the solvent molecule. The oxime (III) was then hydrolyzed with dilute pyruvic acid in acetic acid and afforded $\mathrm{V}$ in $59 \%$ yield. A brief treatment of $\mathrm{V}$ with dilute methanolic sulfuric acid led to the substitution of a hydroxyl group, affording IV in $62 \%$ yield from V.

Oximation of the hydroxy-ketone (V) gave an oxime (VIII), mp 194-195.5 (78\%), which also changed into the original compound (III) quantitatively when treated with dilute methanolic sulfuric acid. On the other hand, when the oxime (VIII) was treated with $p$ toluensulfonyl chloride in pyridine the cyclic imide nitrile (VI) was obtained in $65 \%$ yield. The configuration of angular substituents at C-5 was tentatively assigned as $\alpha$ in accordance

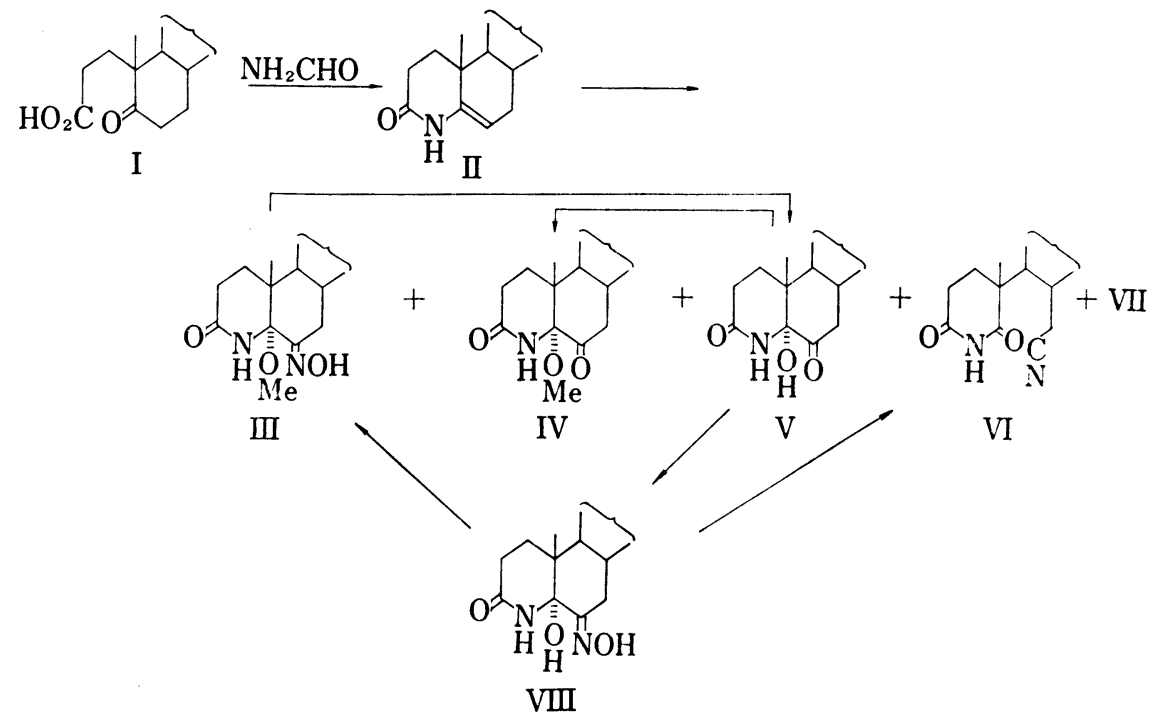

Chart 1

6) H. Suginome and H. Takahashi, Tetrahedron Letters, 1970, 5119. 
with other instances, ${ }^{7)}$ since the hydroxy-ketone (V) showed no significant intramolecular hydrogen bonding in its IR spectrum. These evidences revealed that nitroso ion does not substitute at nitrogen but attacks unsaturated carbon at $\mathrm{C}-6$ in much the same way as in recently reported nitrosation of 5 -chlestene derivatives. ${ }^{7)}$

4-Methyl-4-azacholest-5-en-3-one (IX) showed similar results with sodium nitrite. When treated in acetic acid-acetic anhydride, the products isolated were hydroxy oxime (X), mp. $175.5-176^{\circ}(3.1 \%)$, nitrimine derivative (XI), $\mathrm{mp} 147-150^{\circ}$ (trace), cyclic imide (XII), $\mathrm{mp} 143-144.5^{\circ}$ (trace), and an unidentified product (XIII), $\mathrm{mp} 177.5-178^{\circ}$. The structure of $\mathrm{X}$ was supported by its IR spectrum which showed absorptions at 3580,3300 and 1620 $\mathrm{cm}^{-1}$ and by its NMR which showed a characteristic $7 \beta$-equatorial hydrogen at $\delta 3.34$ as a doublet $(J=12 \mathrm{~Hz})$. The nitrimine (XI) showed a weak absorption at $269 \mathrm{~nm}$ in its ultraviolet (UV) spectrum as reported, ${ }^{8)}$ and one proton, possibly a $7 \beta$-hydrogen, at $\delta 3.31(\mathrm{~d}, J=12 \mathrm{~Hz}$ ) in its NMR spectrum. The cyclic imide nitrile structure of XII was supported by the presence of absorptions at $2250(\mathrm{CN}), 1720$, and $1665 \mathrm{~cm}^{-1}(\mathrm{CO})$. These structures were confirmed by the fact that the sodium nitrite treatment of the compound $(\mathrm{X})$ gave a mixture of $\mathrm{XI}$ and XII. The foregoing reaction processes were assumed as shown in Chart 3 but it is not clear whether the cyclic imide was formed directly from hydroxy oximes or through nitrimine intermediate as in the case of pyrolysis of camphor nitrimine. $\left.{ }^{9}\right)$

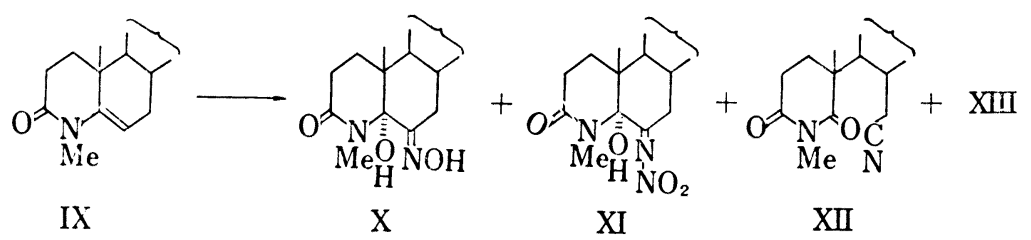

Chart 2

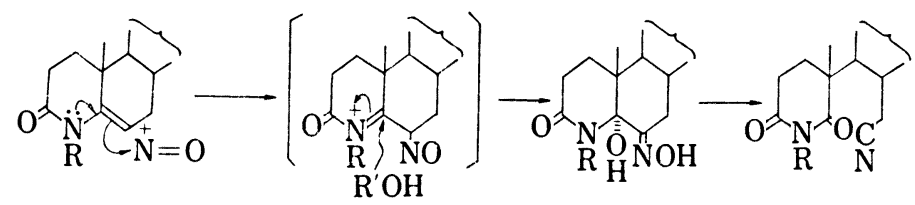

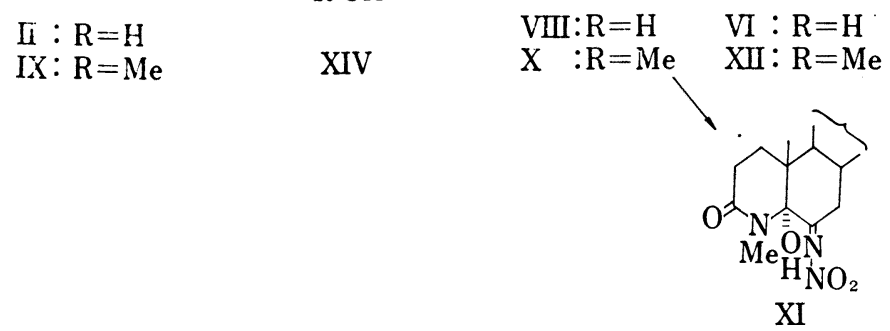

Chart 3

\section{Experimental ${ }^{10}$ )}

4-Azacholest-5-en-3-one (II) _ A solution of $14 \mathrm{~g}$ of seco acid (I) in $94 \mathrm{ml}$ of formamide was heated in an oil bath $\left(180^{\circ}\right)$ for $1.5 \mathrm{hr}$ and left to cool. The mixture was poured into $500 \mathrm{ml}$ of $\mathrm{H}_{2} \mathrm{O}$, the precipitate-

7) C.R. Narayanan, M.S. Parker, and M.S. Wadia, Tetrahedron Letters, 1970, 4703; M. Onda and A. Azuma, Chem. Pharm. Bull. (Tokyo), 19, 859 (1971).

8) C. Shiue, K.P. Park, and L.B. Clapp, J. Org. Chem., 35, 2063 (1970).

9) L.J. Winters, J.F. Fischer, and E.R. Ryan, Tetrahedron Letters, 1971, 129.

10) Melting points were measured on a Kofler's hot stage and are not corrected. NMR spectra were measured. in $\mathrm{CDCl}_{3}$ solution. 
was collocted by suction, washed thoroughly with $\mathrm{H}_{2} \mathrm{O}$, and crystallized from $\mathrm{CHCl}_{3}-\mathrm{MeOH}$ to $13.6 \mathrm{~g}$ of II $(100 \%), \operatorname{mp} 247.5-251^{\circ},[\alpha]_{\mathrm{D}}-90.8^{\circ}\left(c=0.50, \mathrm{CHCl}_{3}\right)$. IR $\nu_{\max }^{\mathrm{Nujol}} \mathrm{cm}^{-1}: 3200,3100,1685,1625 . \quad \mathrm{UV} \lambda_{\max }^{\text {EtOH }}$ $\mathrm{nm}(\log \varepsilon): 233(4.20)$. (reported, $\left.{ }^{11)} \mathrm{mp} 252-253^{\circ},[\alpha]_{\mathrm{D}}-90^{\circ}, \mathrm{UV} \lambda_{\max }^{\mathrm{EtoH}} \mathrm{nm}(\log \varepsilon): 233(4.13)\right)$.

Reaction of II with $\mathrm{NaNO}_{2}$-a) A solution of $3 \mathrm{~g}$ of the lactam (II) in $240 \mathrm{ml}$ of $\mathrm{Ac}_{2} \mathrm{O}$ and $60 \mathrm{ml}$ of $\mathrm{AcOH}$ was mixed with $9 \mathrm{~g}$ of $\mathrm{NaNO}_{2}$ during $3 \mathrm{hr}$ stirring at 0 to $-5^{\circ}$ and poured into 1.5 liter of ice-water. After stirring overnight, the mixture was extracted with $\mathrm{CHCl}_{3}$ and the extract was worked up as usual. The evaporation residue was crystallized from $\mathrm{MeOH}$ to $704 \mathrm{mg}$ of $5 a$-methoxy-6-oximino-4-azacholestan3-one (III), $\operatorname{mp~} 172-173^{\circ},[\alpha]_{\mathrm{D}}+39.9^{\circ}\left(c=1.68, \mathrm{CHCl}_{3}\right)$. IR $v_{\max }^{\text {Noulol }} \mathrm{cm}^{-1}: 3380(\mathrm{OH}), 3200,3100,1675,1660$ (lactam). $\quad$ NMR $\delta: 0.65$ (s, 3H, 18-Me), 0.87 (s, 3H, 19-Me), $2.94(\mathrm{~s}, 3 \mathrm{H}, \mathrm{OMe}), 3.35(\mathrm{~d}, 1 \mathrm{H}, J=12 \mathrm{~Hz}, 7 \beta-\mathrm{H})$, 7.90 (broad s, $1 \mathrm{H}, \mathrm{NH}), 11.92(\mathrm{~s}, 1 \mathrm{H}, \mathrm{OH})$. Anal. Calcd. for $\mathrm{C}_{27} \mathrm{H}_{46} \mathrm{O}_{3} \mathrm{~N}_{2}: \mathrm{C}, 72.60 ; \mathrm{H}, 10.38 ; \mathrm{N}, 6.27$. Found: C, $72.67 ; \mathrm{H}, 10.52 ; \mathrm{N}, 6.39$. The mother liquor was chromatographed over silica gel and crystallized from $\mathrm{MeOH}$ to give $88 \mathrm{mg}$ of $5 \alpha$-methoxy-4-azacholestane-3,6-dione (IV) and $110 \mathrm{mg}$ of $5 \alpha$-hydroxy-4-azacholestane-

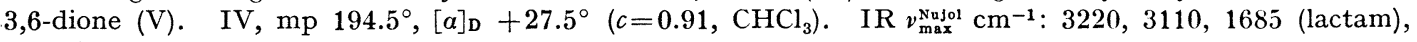
$1739(\mathrm{CO})$.

NMR $\delta: 0.65(\mathrm{~s}, 3 \mathrm{H}, 18-\mathrm{Me}), 0.77$ (s, 3H, 19-Me), 3.00 (s, 3H, OMe), 6.85 (broad s, 1H, NH). Anal. Calcd. for $\mathrm{C}_{27} \mathrm{H}_{45} \mathrm{O}_{3} \mathrm{~N}: \mathrm{C}, 75.13 ; \mathrm{H}, 10.51 ; \mathrm{N}, 3.25$. Found: $\mathrm{C}, 74.91 ; \mathrm{H}, 10.68 ; \mathrm{N}, 3.34$.

$\mathrm{V}, \mathrm{mp} 211^{\circ},[\alpha]_{\mathrm{D}}-20.9^{\circ}\left(c=1.26, \mathrm{CHCl}_{3}\right)$, IR $v_{\max }^{\text {Nujol }} \mathrm{cm}^{-1}: 3300$ (broad, $\mathrm{NH}$ or $\left.\mathrm{OH}\right), 1670,1620$ (lactam), 1735 (CO). NMR $\delta: 0.73(\mathrm{~s}, 3 \mathrm{H}, 18-\mathrm{Me}), 0.85(\mathrm{~s}, 3 \mathrm{H}, 19-\mathrm{Me})$. Anal. Calcd. for $\mathrm{C}_{26} \mathrm{H}_{43} \mathrm{O}_{3} \mathrm{~N}: \mathrm{C}, 74.77 ; \mathrm{H}, 10.83$ $\mathrm{N}, 3.35$. Found: C, 74.61; H, 10.35; N, 3.45.

b) A solution of the lactam (II, $2 \mathrm{~g}$ ) in $40 \mathrm{ml}$ of $\mathrm{Ac}_{2} \mathrm{O}$ and $10 \mathrm{ml}$ of $\mathrm{AcOH}$ was treated with $2 \mathrm{~g}$ of $\mathrm{NaNO}_{2}$ at $0^{\circ}$ for $9 \mathrm{hr}$ in the dark and worked up as above.

The mixture was chromatographed over silica gel and the fractions were allowed to crystallize in $\mathrm{MeOH}$. From these, V (217.5 mg), 5,6-seco-4-azacholestane-3,5-dione-6-carbonitrile (VI) (89.4 mg), and VII (6 mg) were obtained in pure form.

$\mathrm{VI}, \mathrm{mp} 154-155^{\circ},[\alpha]_{\mathrm{D}}+197.2^{\circ}\left(c=1.07, \mathrm{CHCl}_{3}\right) . \quad$ IR $v_{\max }^{\mathrm{Nujol}} \mathrm{cm}^{-1}: 3200,3100(\mathrm{NH}), 2250(\mathrm{CN}), 1720$, 1700 (CO). NMR $\delta: 0.70(\mathrm{~s}, 3 \mathrm{H}, 18-\mathrm{Me}), 1.23(\mathrm{~s}, 3 \mathrm{H}, 19-\mathrm{Me})$. A nal. Calcd. for $\mathrm{C}_{26} \mathrm{H}_{42} \mathrm{O}_{2} \mathrm{~N}_{2}: \mathrm{C}, 75.31 ; \mathrm{H}$, $10.21 ; \mathrm{N}, 6.76$. Found: $\mathrm{C}, 75.28 ; \mathrm{H}, 10.21 ; \mathrm{N}, 6.95$.

VII, $\operatorname{mp} 224-225.5^{\circ}$ (decomp). $[\alpha]_{\mathrm{D}}+70.0^{\circ}\left(c=1.00, \mathrm{CHCl}_{3}\right) . \quad$ IR $\nu_{\max }^{\text {Nujol }} \mathrm{cm}^{-1}: 3180,3100,1680$. Anal. Found: $\mathrm{C}, 77.58 ; \mathrm{H}, 11.24 ; \mathrm{N}, 3.52$.

c) A mixture of the lactam (II, $2 \mathrm{~g}$ ) in $60 \mathrm{ml}$ of $\mathrm{AcOH}-\mathrm{Ac}_{2} \mathrm{O}(1: 5)$ was chilled to $-5^{\circ}$ in the dark then $1.6 \mathrm{~g}$ of $\mathrm{NaNO}_{2}$ was added and stirred for $c a .2 \mathrm{hr}$. Pyridine $(1 \mathrm{ml})$ and $20 \mathrm{ml}$ of $\mathrm{H}_{2} \mathrm{O}$ were added gradually with cooling and the mixture was poured into $\mathrm{H}_{2} \mathrm{O}$. After extraction with $\mathrm{CHCl}_{3}$ and working up the extract as usual, the solvent was evaporated in vacuo. The oily residue was dissolved in $20 \mathrm{ml}$ of hot $\mathrm{MeOH}$ and left to cool. The precipitate was collected by suction and recrystallized from $\mathrm{MeOH}$ to $0.4 \mathrm{~g}$ of colorless powdery crystals, $\mathrm{mp} 212^{\circ}$, which was identified with $\mathrm{V}$ by spectral data and TLC.

Reaction of III with $\mathrm{NaNO}_{2}$ in Polyphosphoric Acid-A mixture of $1 \mathrm{~g}$ of II and $30 \mathrm{~g}$ of polyphosphoric acid was treated with $360 \mathrm{mg}$ of $\mathrm{NaNO}_{2}$ with manual stirring at room temperature for 10 min and then poured into ice-water. The mixture was extracted with $\mathrm{CHCl}_{3}$ and the extract was worked up as usual. After evaporation of the solvent, the residue was dissolved in $30 \mathrm{ml}$ of $\mathrm{MeOH}$ and refluxed for $30 \mathrm{~min}$. When cooled, the precipitate was collected by suction to $1.32 \mathrm{~g}$ of crude III. Recrystallization from $\mathrm{MeOH}$ gave $924 \mathrm{mg}$ of pure III as colorless plates, $\mathrm{mp} 173-174^{\circ}$. IR $v_{\max }^{\mathrm{Nujo1}} \mathrm{cm}^{-1}: 3375,3200,3100,1675,1600$.

Hydrolysis of III-A mixture of $25 \mathrm{mg}$ of III, $12 \mathrm{ml}$ of $50 \%(\mathrm{v} / \mathrm{v})$ pyruvic acid, and $2 \mathrm{ml}$ of AcOH was warmed at $90^{\circ}$ for $4 \mathrm{hr}$. The solution was diluted with $\mathrm{H}_{2} \mathrm{O}$ and extracted with $\mathrm{CHCl}_{3}$. After working up the extract as usual, the residue was crystallized from $\mathrm{MeOH}$ to give $\mathrm{V}, \mathrm{mp} 210-211.5^{\circ}(13.7 \mathrm{mg}, 59 \%)$, IR $v_{\max }^{\text {Nujol }} \mathrm{cm}^{-1}: 3300,1735,1670,1620$.

Oximation of $\mathrm{V}$ - A solution of $\mathrm{V}(120 \mathrm{mg})$ in $1 \mathrm{ml}$ of pyridine was treated with $30 \mathrm{mg}$ of $\mathrm{HONH}_{2}-\mathrm{HCl}$ at $90^{\circ}$ for $10 \mathrm{~min}$. The solution was poured into $\mathrm{H}_{2} \mathrm{O}$, extracted with $\mathrm{CHCl}_{3}$, and the extract was worked up as usual. The residue was chromatographed over silica gel and crystallized from $\mathrm{CHCl}_{3}-\mathrm{hexane}(1: 3)$

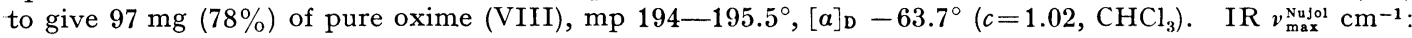
3300, 3150, 1635. NMR $\delta: 0.65(\mathrm{~s}, 3 \mathrm{H}, 18-\mathrm{Me}), 0.90(\mathrm{~s}, 3 \mathrm{H}, 19-\mathrm{Me}), 3.25(\mathrm{~m}, 2 \mathrm{H})$. Anal. Calcd. for $\mathrm{C}_{27} \mathrm{H}_{46} \mathrm{O}_{3}-$ $\mathrm{N}_{2}$ : C, 72.60; H, 10.38; N, 6.27. Found: C, 72.09; H, 10.42; N, 6.44.

Transformation of VIII into III-The oxime (VIII, $6.7 \mathrm{mg}$ ) was dissolved in $0.5 \mathrm{ml}$ of $1^{\circ} \mathrm{H}_{2} \mathrm{SO}_{4}$ in $\mathrm{MeOH}$ with warming and then allowed to crystallize at room temperature. The product collected was identified as the methoxy oxime (III, $6.8 \mathrm{mg}, 98 \%$ ) by IR spectrum and mixed $\mathrm{mp}$.

Transformation of VIII into VI-A solution of VIII $(22 \mathrm{mg})$ in $1 \mathrm{ml}$ of pyridine was treated with $29 \mathrm{mg}$ of $p$ - $\mathrm{TsCl}$ at room temperature for $22 \mathrm{hr}$. The mixture was poured into $\mathrm{H}_{2} \mathrm{O}$, extracted with $\mathrm{CHCl}_{3}, \mathrm{H}$ the extract was submitted to preparative TLC using $\mathrm{CHCl}_{3}$-ether $(2: 3)$ as a solvent system. The main band was extracted and recrystallized from $\mathrm{MeOH}$ to $14.1 \mathrm{mg}(65 \%)$ of cyclic imide nitrile (VI), mp $154-155$. $^{\circ}$ IR $v_{\max }^{\mathrm{Nujo1}} \mathrm{cm}^{-1}: 3200,3100,2250,1720,1700$.

11) C.W. Shoppee, R.W. Killick, and G. Kruger, J. Chem. Soc., 1962, 2275. 
Transformation of $\mathbf{V}$ into IV - A solution of $20 \mathrm{mg}$ of $\mathrm{V}$ in ca. $2 \mathrm{ml}$ of $1 \% \mathrm{H}_{2} \mathrm{SO}_{4}$ in $\mathrm{MeOH}$ was refluxed for $1 \mathrm{~min}$, then left to cool. After crystallization, $12.7 \mathrm{mg}(62 \%)$ of IV, mp $194-195^{\circ}, \mathrm{IR}_{\mathrm{max}^{\mathrm{Nuj}}}^{\mathrm{Nu}} \mathrm{cm}^{-1}: 3200$, $3100,1740,1685$, was obtained.

N-Methyl-4-azacholest-5-en-3-one (IX)__ A solution of $7 \mathrm{~g}$ of seco-acid (I) in $20 \mathrm{ml}$ of methylformamide was heated in an oil bath $\left(160^{\circ}\right)$ for $4 \mathrm{hr}$ and left to cool. The precipitate was collected by suction, washed thoroughly with $\mathrm{H}_{2} \mathrm{O}$, and dried. Yield, $4.5 \mathrm{~g}(70 \%)$. mp 98-100 ${ }^{\circ},[\alpha]_{\mathrm{D}}-105.4^{\circ}\left(c=0.94, \mathrm{CHCl}_{3}\right)$. IR $v_{\max }^{\text {Nujol }} \mathrm{cm}^{-1}: 1675,1645$. NMR $\delta: 0.70(\mathrm{~s}, 3 \mathrm{H}, 18-\mathrm{Me}), 1.03(\mathrm{~s}, 3 \mathrm{H}, 19-\mathrm{Me}), 3.10(\mathrm{~s}, 3 \mathrm{H}, \mathrm{NMe}), 5.03$ (d, doublet, $1 \mathrm{H}, J=6,1.5 \mathrm{~Hz}$ )

Reaction of IX with $\mathrm{NaNO}_{2}$ - A solution of $1 \mathrm{~g}$ of the lactam (IX) in $40 \mathrm{ml}$ of $\mathrm{Ac}_{2} \mathrm{O}$ and $10 \mathrm{ml}$ of $\mathrm{AcOH}$ was mixed and stirred with $180 \mathrm{mg}$ of $\mathrm{NaNO}_{2}$ at $0^{\circ}$ for $2 \mathrm{hr}$. Pyridine $(1 \mathrm{ml})$ and $50 \mathrm{ml}$ of $\mathrm{H}_{2} \mathrm{O}$ was added, the mixture was stirred further for $30 \mathrm{~min}$, and then poured into ice-water. The mixture was extracted with $\mathrm{CHCl}_{3}$ and the extract was worked up as usual. After evaporation of the solvent, the residue was submitted to preparative TLC and separated into 4 components; X (34.2 mg), XI (22.5 mg), XII (9 mg), and an unidentified product (XIII, $22.5 \mathrm{mg}$ ).

$\mathrm{X}, \mathrm{mp} 175-176^{\circ}$ (from ether-Petr-ether), $[\alpha]_{\mathrm{D}}-15.8^{\circ}\left(c=0.95, \mathrm{CHCl}_{3}\right) . \quad$ IR $\nu_{\max }^{\mathrm{Nujol}} \mathrm{cm}^{-1}: 3370-3130$ 1605, $v_{\max }^{\mathrm{CHCl}_{\mathrm{s}}} \mathrm{cm}^{-1}: 3580,3300,1640 . \quad \mathrm{NMR} \delta: 0.66(\mathrm{~s}, 3 \mathrm{H}, 18-\mathrm{Me}), 0.85(\mathrm{~s}, 3 \mathrm{H}, 19-\mathrm{Me}), 2.74(\mathrm{~s}, 3 \mathrm{H}, \mathrm{NMe})$, $3.34(\mathrm{~d}, 1 \mathrm{H}, J=12 \mathrm{~Hz}, 7 \beta-\mathrm{H})$. Anal. Calcd. for $\mathrm{C}_{27} \mathrm{H}_{46} \mathrm{O}_{3} \mathrm{~N}_{2}: \mathrm{C}, 72.60 ; \mathrm{H}, 10.38 ; \mathrm{N}, 6.27$. Found: $\mathrm{C}, 72.50$; $\mathrm{H}, 10.46 ; \mathrm{N}, 5.87$.

$\mathrm{XI}, \mathrm{mp} 147-150^{\circ}$ (from $\left.\mathrm{MeOH}\right),[\alpha]_{\mathrm{D}}+10.9^{\circ}\left(c=1.05, \mathrm{CHCl}_{3}\right) . \quad \mathrm{UV} \lambda_{\max }^{\mathrm{EtOH}} \mathrm{nm}(\log \varepsilon): 269(2.78) . \quad$ IR $v_{\max }^{\text {Nujol }} \mathrm{cm}^{-1}: 3250,1665,1575,1315$. $\operatorname{NMR} \delta: 0.65(\mathrm{~s}, 3 \mathrm{H}, 18-\mathrm{Me}), 0.84(\mathrm{~s}, 3 \mathrm{H}, 19-\mathrm{Me}), 2.74(\mathrm{~s}, 3 \mathrm{H}, \mathrm{NMe})$, $3.31(\mathrm{~d}, 1 \mathrm{H}, J=12 \mathrm{~Hz}, 7 \beta-\mathrm{H})$. Anal. Calcd. for $\mathrm{C}_{27} \mathrm{H}_{45} \mathrm{O}_{4} \mathrm{~N}_{3}: \mathrm{C}, 68.17 ; \mathrm{H}, 9.57 ; \mathrm{N}, 8.84$. Found: C, 68.43; $\mathrm{H}, 9.82 ; \mathrm{N}, 8.57$.

XII, mp $143-144.5^{\circ}$ (from $\left.\mathrm{MeOH}\right),[\alpha]_{\mathrm{D}}-128.1^{\circ}\left(c=0.95, \mathrm{CHCl}_{3}\right) . \quad$ IR $v_{\max }^{\text {vujol }} \mathrm{cm}^{-1}: 2245,1720,1665$. NMR $\delta: 0.70(\mathrm{~s}, 3 \mathrm{H}, 18-\mathrm{Me}), 1.23(\mathrm{~s}, 3 \mathrm{H}, 19-\mathrm{Me}), 3.20(\mathrm{~s}, 3 \mathrm{H}, \mathrm{NMe})$. Anal. Calcd. for $\mathrm{C}_{27} \mathrm{H}_{44} \mathrm{O}_{2} \mathrm{~N}_{2}: \mathrm{C}_{2}, 75.65$; $\mathrm{H}, 10.35 ; \mathrm{N}, 6.54$. Found: $\mathrm{C}, 75.60 ; \mathrm{H}, 10.47 ; \mathrm{N}, 6.38$.

XIII, $\operatorname{mp} 177.5-178^{\circ},[\alpha]_{\mathrm{D}}+150^{\circ}\left(c=1.00, \mathrm{CHCl}_{3}\right) . \quad$ IR $\nu_{\max }^{\text {Nujol }} \mathrm{cm}^{-1}: 1700,1660 . \quad$ Anal. Found: $\mathrm{C}, 77.84$; $\mathrm{H}, 11.34 ; \mathrm{N}, 3.33$. 